\title{
Calvin on preaching
}

L F Schulze

Professor Emeritus: Department of Dogmatology and Ecclesiology

Potchefstroom University for Christian Higher Education

\begin{abstract}
After introducing the congregation of Geneva to whom Calvin preached, the topic of this paper is discussed under the headings of three questions namely: Why did he preach? How did he preach? and, What did he preach? By answering these questions Calvin's view on preaching is elucidated.
\end{abstract}

\section{INTRODUCTION: THE CONGREGATION}

$\mathrm{Oh}$, they came, the inhabitants of Geneva; they came to the services at St Pierre, or St Gervais, or la Madeleine (cf Parker 1992:59), because the city council has decreed attendance at church services compulsary (Peter 1984:31). At least - most of them came. Nevertheless, there are always the brave of heart - even in Calvin's time who could get away, even by defying a decree (CO 8:420,435; Peter, 1984:32-33) ${ }^{1}$. Some came to hear the Word of God, a few came, even from afar, to hear Calvin preach (Exalto 1982:79); others came in order to avoid a confrontation with the elders (the consistoire), or even with the city police (Doumergue 1909:7).

They entered St Pierre, stripped of its colourful Roman-Catholic images, containing a few pews but many chairs which, by courtesy of the men, were occupied by women. The standing room at the back was filled by men - some to hear, some indifferent, some grudging, some to heckle and criticize (Doumerge 1909:7-8).

To this ecclesia permixta Calvin preached the Word. Like Luther and Zwingli he saw his main charge in the systematic exposition of the Bible - book by book, chapter by chapter, verse by verse (Mülhaupt 1931:17). As such this method was not new; it was followed by teachers at seminaries during the Middle Ages. What was new indeed was the fact that systematic exegesis was moved from the seminaries and universities to the market squares, from the ears of a few exclusive semenarians to the masses, to the people, their magistrates, and their kings (cf Mülhaupt 1931:18).

Seeing in the mind's eye Calvin in the pulpit, speaking fairly slowly and softly because of his asthmatic condition, three simple questions emerge, claiming our attention: why did he preach, how did he preach, what did he preach? 


\section{WHY DID HE PREACH?}

\subsection{The first answer}

The first answer to this question may be gleaned by looking into the court of St Pierre. In the south western corner is a bronze statue overlooking the city. It is the last work of the Swiss impressionist sculptor August von Niederhaüsern (1863-1913), erected by the municipality of Geneva in 1938 - indeed an apt gesture. It represents the prophet Jeremiah. 'Looking at it, one could believe to recognize Calvin fighting for the honour of God and the salvation of the Genevans' (Peter 1971:16).

An apt gesture by the Genevan municipality, for Calvin did have a special affinity for the prophet from Anathoth ${ }^{2}$. Perhaps the glowing sunlight is shed on the statue by Lamparter's title of his commentary on Jeremiah: Prophet wider Willen (1964).

A prophet against his will - hat was Jeremiah; that was also Calvin. He had occasionally preached in the vicinity of Noyon before his definitive move to the Reformation (Mülhaupt 1931:3-4; Exalto 1982:79), but having fled from France, he intended to move from Geneva to the peace of Strasbourg in order to proceed with his studies. The stern adjuration of Farel, however, constrained the timid and frightened Calvin to stay in Geneva as a teacher. Eventually he also had to preach, and, after his more happy sojourn at Strasbourg, came back in 1541 with resignation to resume his task in Geneva. He therefore exhibited in his own life as a preacher the meaning of Chrysostom's words: 'The foundation of our philosophy is humility' (Inst 2.2.11).

\subsection{Some oblique answers}

Some more answers to the question above lie beneath the surface of Calvin's exposition of the importance - or the necessity and authority, if you like - of Scripture. Calvin says (Inst 1.6.2):

If true religion is to beam upon us, our principle must be; that it is necessary to begin with heavenly teaching, and that it is impossible for any man to obtain even the minutest portion of right and sound doctrine without being a disciple of Scripture. Hence the first step in true knowledge is taken, when we reverently embrace the testimony which God has been pleased therein to give of himself. For not only does faith, full and perfect faith, but all correct knowledge of God, originate in obedience. And surely in this respect God has with singular Providence provided for mankind in all ages. 
Let us note: not only faith, but all true knowledge of God 'originate(s) in obedience', which means to embrace the testimony of God which he gives of himself in Scripture.

Obedience in this context refers primarily to the obligation of all Christians. However, it also sheds light on the question why Calvin preached, or more specifically, why this Jeremiah of the 16th century had to preach, viz not only because of the pressing situation in Geneva, but above all because of his divine charge. 'The impulsion, or compulsion, to preach was theological. Calvin preached because he believed (Parker 1992:1; cf Douma \& V d Vegt 1978:8). The above quoted lines from the Institutes reveal even more answers to the question why Calvin preached - answers which were given more explicitly elsewhere in his works. It is impossible to look attentively to each answer. Let us then simply glance at two of them in passing.

* The necessity of the Bible for true knowledge and faith firstly entails the necessity of preaching (Biesterveld 1897:9-12; Peter 1971:50; cf Inst 4.1.5). Parker (1992: 8-16) speaks in this respect of 'the pastoral impulsion' to preach. God gives us sermons, says Calvin, 'to draw us to him, it is as if he extends his hands to us' (S Jer 17:11-14 - SC 6:117), and 'the preaching of the Gospel is not without reason called the visitation of God' (Com Jer 32:33). Preaching is a sure sign that Christ has not deserted us, that he is present and his voice audible (cf Douma \& v d Vegt, 1978:11). Therefore, private Bible reading is not sufficient. The congregation must convene to be instructed, for preaching is like a mother breaking bread for her infants and putting the crumbs in their mouths that they can eat (S 12 sur 2 Tm CO 54:150-151, quoted by Peter 1971:50, n 9).

Negatively stated: whithout preaching, the work of Christ would be rendered futile and the existence of the church would vanish (Douma \& V d Vegt 1978:6).

* Answering obliquely the question why he preaches, Calvin secondly points to the purpose of preaching. Formulating its aim in various ways, Calvin points to conversion: 'The Gospel is preached to us in order that our vices should be extirpated in such a way that God would appear to reign in our midst' (S Act 5:13-16 - SC 8:46). Preaching is to declare the judgments of God to the evil-doers in order to accuse them and convict them of their vices (S Act 6:1-6 - SC 8:214; cf Parker, 1992:13). But if one speaks only of the threats and judgments of God, remarks Calvin, it would lead us to despair (S Act 7:8-9 - SC 8:262). Therefore Calvin 
mentions edification as a more comprehensive aspect of the purpose of preaching, including in it the affection of the preacher. He says (S 24 sur $2 \mathrm{Tm}$, quoted by Parker 1992:11-12):

When I expound Holy Scripture, I must always make this my rule: That those who hear me may recieve profit from the teaching I put forward and be edified unto salvation. If I have not that affection, if I do not procure the edification of those who hear me, I am a sacrilege profaining God's Word 3 .

The ultimate purpose of preaching is to communicate Christ to sinners estranged from God (Exalto 1982:82). By the preaching of his Gospel, says Calvin, we participate daily in all the benefits Christ has acquired for us (S Act 4:21-26 - SC 8:102).

Not the way of mysticism, but the way of the church, the way of preaching, is the way to God. It is also the way of God, present in the power of the Holy Spirit, toward the formation of a new heaven and a new earth. This was the firm conviction of Calvin (cf S Act 7:52-56 - SC 8:384; com Is 43:19; 65:17; 2 Cor 5:17). That was why we see Calvin so often ascending the pulpit - six times a week every second week. By fulfilling his divine charge abediently, preaching itself becomes an exaltation of God. Parker (1992:46) says:

The preacher's purpose is directed first of all towards God ... The very act of declaring the Gospel is a praising and exalting of God in his mighty acts. Every preaching of God's Word is a Te Deum Laudamus ... And when the purpose is directed towards man it does not lose its character of praise of God, for it is he who saves, who reforms lives, who cares for and preserves, and therefore is to be thanked, worshipped.

\section{HOW DID HE PREACH?}

But now, when an unpolished simplicity, almost bordering on rudeness, makes a deeper impression than the loftiest flight of oratory, what does it indicate if not that the Holy Scriptures are too mighty in the power of truth to need the rhetorician's art?

(Inst 1.8.1) 
These words of Calvin about Scripture apply also to his exposition of the divine Word in preaching. His sermons bear no trace of oratorical eloquence, no sign of rhetorical sweetness and artificiality. Above all, the sermons exhibit no predeliction for the allegorical method, so beloved since Origen. On the contrary, allegorizing is 'a liberty allowed of adulterating the genuine meaning of Scripture', and by this means 'the ancients recklessly played with the sacred word of God, as if it had been a ball to be tossed to and fro' (Com 2 Cor 3:6). Scripture, though, is not like 'a nose of wax' (nez de cire) which can be twisted in any way the interpreters likes (cf Schulze 1971:79 n 34). Calvin abhorred allegorizing because it was a sure method to turn the immutable Word of God into 'words of wind,' thus annihilating the very foundation of 'edification' and together with it, the verity and fidelity of God himself.

Passing these remarks, let us listen for a while how Calvin preached to the congregation, some of whom were living in the city, others on farms, some educated, others illiterate.

\subsection{Preaching simply}

The 'unpolished simplicity' of Scripture (Inst 1.8.1) is reflected in many examples of Calvin's down to earth preaching. Listen to two cases.

(a) Admonishing the congregation to be pleased to receive God's Word and not to make the preacher's task harder by expecting him to speak according to their fancies, he says in a sermon on 1 Timothy 4:6-7 (sermon 31), as quoted by Parker (1992:52):

Now, just as many preachers are themselves far too given to ambition and in order to find grace and favour seek only what will please, so also on the other side the people are the cause of making preachers swerve aside from the good way. And why? Because, as St Peter says (in fact, $2 \operatorname{Tm} 4: 3$ ) men have 'itching ears' and want to be fed pleasing stories and buffoonery of 'old wives' fables,' as St Paul calls them here. Seeing that men have such desires - like pregnant women whose cravings are inordinate - ah well! this is the cause of some preachers degenerating and disguising themselves and transforming God's teaching, which is as bad as destroying it (CO 53:371-372). 
(b) Expounding the words nourished up in words of faith (I Tm 4:6) Calvin can even allow himself playfully 'a little character sketch' (Parker 1992:147). Again ministers and their task (i $\mathrm{c}$ to nourish) has his attention, but now it is (as suggested by the text) cast in a female form. Parker (1992:147- of CO 53:376) translates as follows:

Take the case that there is a nurse who is a gossip and a drunkard. Ah well! she can cackle, she can make it look as if the baby is all the world to her. Mais quoy? She is just a drunkard, full of intemperance and talk. Instead of sleeping at night, she gives herself up to lechery, so that she has not milk; and the poor child gets no nourishment. She, on the contrary, who will work willingly and yet take substantial nourishment, as well as sleeping properly, she will be able to nourish her baby as well. So is it with those who have to proclaim the Word of God.

The unpolished simplicity is everywhere visible in his language. Accommodating himself to the everyday life and cognitive capacity of his congregation, he sometimes speaks the language of farmers. We hear about fields that rest, 'lying fallow, as one says', about the clammy fog that ruins the wheat crop; about re-tilling a land when seedlings from the first sowing do not show (Doumergue 1909:14).

Sometimes the exposition is framed in the form of a lively dialoque in order to hold the attention of the congregation. So, for instance, Calvin could have explained to his congregation that, if Moses were like us, he would have responded to the command to go up the mountain (Ex 19:20), by saying that it would be exhausting and even dangerous. Instead of this, Calvin let us hear Moses himself: 'Ha! that is beautiful', he cried out. 'I am going to break my legs by going up to the top! And ... I will see. Now, at this moment, not yet' (Doumergue 1909:15 - my free translation form the Dutch).

God accomodates his word to our feeble perception, says Calvin. As a preacher he did the same because a doctrine declared in general is ineffective - it must be 'put into the hands' (Com Jr 18:11; Pt 1971:53).

However, let us not be deceived by Calvin's simple vocabulary (Parker 1992:41) and his easy-going sermons as if they were only ad libido cheap talk. Parker (1992:87) has shown the deep and encompassing knowledge 'that lies, nearly always concealed, behind Calvin's deceptively simple expanations of his author's meaning.' 


\subsection{Preaching vehemently}

By way of introduction a paragraph from Parker's book (1992:14) can disclose why Calvin often preached so vehemently:

But even reproof is not ecough by itself. It must be accompanied by correction: 'that is, that we may be, so to say, chastised by God's Word, to reform us, so that we may be drawn out of our vices' (CO 54:290). If we have really been deeply sunk in vices the preacher must use force and violence if they are to be uprooted and thrown out. 'When a father sees his children going badly astray, he will not be content just to say to them, 'What are you up to, my children?' That would be neither right nor good. He will say, 'Unhappy creatures! Have I brought you up, have I provided for you until now, only for you to pay me back like this? ... Go, wretch! you deserve to be in the hangman's hands ... Must I nourish such scum in my house?' (CO 54:290). And will not God be angry with us who have behaved far worse to him than any earthly child to its father? Not, of course, that God loses his temper; but he uses vehemence to beat us down and make as submissive to him.

Parker quotes here from a sermon preached in July 1555 on 2 Timothy 3:16-17 (Sermon 23 on $2 \mathrm{Tm}-\mathrm{CO} 54: 283 \mathrm{ff}$ ): "All Scripture is divinely inspired and is profitible for teaching ... that the man of God may be whole, furnished to every good work'. It is indeed written here that Scripture is profitable for reproof, for correction, for training. However, to grasp the vehemence of Calvin's application of this text, the enigma of Geneva must be taken into account. On the one hand Geneva was a beacon, casting its light over Europe. Time and again Calvin stressed in his sermons the 'singular grace' God has bestowed upon this city by erecting his temple and his reign there, by giving the Genevans his pure Gospel, by letting them live in peace while the rest of the world is at war. Geneva was indeed 'a miracle,' willed by the providence of God (cf Peter 1984:26-28). On the other hand the Genevans did not show temselves worthy of this singular divine favour. No, everyone is occupied by his own needs: Some will go to their fields, other will drink, some will play, others prefer their domestic tranquility (Peter 1984:33).

In this context Calvin lashed out in the above sermon on 2 Timothy:

There were some disgusting scoundrels who a little while back disgorged their Consummatum est [it is fulfilled] — and that in all the taverns (I 
had to resist them very vehemently in my preaching); so that these rascals made up a common slogan in their ... taverns: 'No more Law or Prophets for us!'

(Quoted by Parker 1992:9)

Even in his vehemence Calvin remains the pastor, using the profitability of the Word for reproof and correcting to bring - God willing - obdurate man to docility.

\section{WHAT DID HE PREACH?}

Since the purpose of preaching is to communicate Christ and his gifts to alienated sinners, it is obvious that Calvin's preaching has a pronounced Christological character.

Looking at the heart of his preaching from another side, we see him stressing that faith comes from hearing ( $\mathrm{Rm} \mathrm{10),} \mathrm{which} \mathrm{means} \mathrm{that} \mathrm{preaching} \mathrm{should} \mathrm{lead} \mathrm{to} \mathrm{the} \mathrm{pre-}$ eminent gift of the Spirit, viz faith (Inst 3.2.1) as a complete trust in the fatherly benevolence of God towards us, founded on a free promise in Christ (Inst 3.2.7).

In the third sermon on 1 Timothy ( $1 \mathrm{Tm} \mathrm{1:5-CO} \mathrm{53:31)} \mathrm{Calvin} \mathrm{starts} \mathrm{with} \mathrm{a} \mathrm{sort}$ of summary of true faith (i e faith as content) or 'true doctrine,' which includes knowledge of what our God is like; knowing by experience that he is our Father; resting in him entirely and calling boldly upon him with no doubt that he will hear us, that he wishes to help us in our need and that we await the salvation he has promised to us. Calvin then immediately proceeds to enlarge and explain this summary: The faith of which St Paul speaks is that we may be assured what our God is like; that we adore him; that no one fabricates idols in his head; that we do not have an invented God; that we may know that the living God has revealed himself to us and has adopted us by his free goodness in order that we can have recourse to him and boldly call him our Farther, because our sins are pardoned in the name of our Lord Jesus Christ and, being members of him, we know that God holds us as children (cf Parker 1992:94).

In a nutshell Calvin concludes: 'So, then, our faith must look to our Lord Jesus Christ and our view must be fastened entirely on him, or else we cannot approach God his Father - for in ourselves we are too far away. All that, as I have said, is contained in the Law (quoted by Parker 1992:95).

Calvin's reference to 'the Law' here should draw our attention to two points: first, that true knowledge of God - that is faith - is already contained in the Old Testament as its central message; second, that the New Testament simply sheds a brighter light on this message without giving us a fundamental new revelation (cf also Inst $2.10 \& 11$ ). 
Parker (1992:95-96) gives three other examples of 'the sum of the pure doctrine which ought to be preached' (1992:95), which have much the same contents as the one referred to above, exept for an occasional accent on the depravity of man (Sermon 47 on $\mathrm{Tm}$ - CO 53:557).

Note the positive, even joyous, character of Calvin's summary of faith, as given above. Note also what he was preaching. It is nothing but euangelion, (glad tidings) or, to put it in Parker's (1992:97) striking words: '... only one subject is being treated throughout - God as he gives himself to be known by us in Jesus Christ. All that is said about man not only depends on this one subject but is also, strictly speaking, a part of it'.

\section{CONCLUSION}

In the mind's eye we have seen St Pierre with its few pews and many chairs; we have heard the hecklers, some in a half drunken stupor (Peter 1984:33) at the back of the Church. However, we have also heard this single minded preacher, innately a man of warm friendliness (Wallace 1988:292), but often sternly teaching the Word of God, book by book. He was nothing but a tool, a herald of God, trying by the simplicity of his language and the severity of his admonitions to put the Word into their hands. If we could have heard his sermon on Psalm 80:9-20, we would have known that he wanted even more than the Word in their hands. In this sermon Calvin referred to Isaiah, who wanted to sing a song to his beloved (Is 5) and said: 'He is not satisfied to bring the doctrine simply to the people, but he wants that one should make a song of it, and that everyone would learn it, that each and all should have it ringing in their ears'. (SC 7:7; cf Mülhaupt 1981: 24-28).

Indeed, the Word should penetrate the hart and be reflected in a song.

\section{End Notes}

1 The following abbreviations are used:

CO: Calvini opera; Com: Commentary; S: Sermon (sur); SC: Supplementa Calviniana (Sermons inédits). Quotations from the sermons either free or in quotation marks, are mine, unless otherwise stated.

2 In the Baker Book House reprint of Calvin's commentaries (1979), that on Jeremiah is the only one to fill more than two volumes. Peter $(1971: 16)$ points to the density of sermons per chapter in Jeremiah and estimates that Calvin has preached 275 sermons on Jeremiah, of which only 25 came down to us (Peter 1971:14). Calvin was bearing a word similar to that which Jeremiah announced (S 21 sur Dn - CO 41:540). 
3 Note however, Parker's relevant remarks (1992:46): 'When we come to Calvin's most frequently expressed and most comprehensive statement of purpose, it would be a travesty to regard it as some private aim of the preacher. For in the concept of 'edification' it is God who is active and effective, the preacher merely a tool that he uses'. Cf Calvin's description of edification (Sermon 62 on Job 16:3) 'He calls 'words of wind' where there is no resolution (fermete); that is to say, which cannot edify a man .... For when it is a question of a man being taught for his salvation it is said that one edifies him. How? In that he is founded and then afterwards that one builds on it, so that he is confirmed in the fear of God, he is confirmed in the Law, he is confirmed in patience to bear afflictions steadfastly ... (quoted by Parker 1992:47).

\section{Works Consulted}

Biesterveld, P 1897. Calvijn als bedienaar des Woords. Kampen: Bos.

Calvin, J 1971. Sermons sur les Livres de Jérémie et des Lamentations. Publiés par $\mathbf{R}$

Peter. Neukirchen-Vluyn: Neukirchener Verlag des Erziehungsvereins. (Suppl Calvinia, vol 6.)

1864-1897. Ioannes Calvini opera quae supersunt omnia, ed by Baum, Cunitz \& Reuss. Brunsvigae: Schwetschke et Filium.

1981. Psalmpredigten, Passions-, und Pfingstpredigten. Hrsg von E Mülhaupt. Neukirchen-Vluyn: Neukirchener Verslag des Erziehungsvereins. (Supplementa Calviniana, vol 7.)

- 1994. Sermons on the acts of the Apostles, ed by W Balke and W H Th

Moehn. Neukirchen-Vluyn: Neukirchener Verslag des Erziehungsvereins. (Suppl Calviniana, vol 8.)

Douma, J, and Van der Vegt, W H 1978. Inleiding: Het gepredikte Woord, dl 1 Derde druk. Franeker: Wever.

Doumergue, E 1909. Calvijn de prediker van Genève, vertaal deur J C Rutgers. Kampen: Kok.

Exalto, K 1982. Een homiletische Wegwijzer, in Den Boer, C, Van Brummelen, A, Exalto, K, Transponeren. 77-144. Kampen: Kok. (Homiletische handreiking 1.)

Lamparter, H 1964. Prophet wider Willen. Stuttgart: Calwer. (Die Botschaft des Alten Testaments, 20.)

Mülhaupt, E 1931. Die Predigt Calvins. Berlin: De Gruyter. 1981. Einleitung, in SC 7: VII-LIV.

Parker, T H L 1992. Calvin's preaching. Louisville, Kent: Westminister, John Knox Press.

Peter, R 1984. Genève dans la prédication de Calvin, in Neuser, W (Hrsg), Calvinus ecclesiae genevensis custos, 23-48. Frankfurt a M: Peter Lang.

1971. Introduction, in SC 6: VII-LXII.

Schulze, L F 1971. Calvin's reply to Pighius. Potchefstroom: Pro Rege.

Wallace, R S 1988. Calvin, Geneva, and the Reformation. Grand Rapids: Baker. 